\title{
Mediating Role of Boredom in the Workplace on Turnover Intention: A Proposed Framework
}

Micheal Teng, Zaiton Hassan, Mark Kasa, Nik Norsyamimi Md Nor, Nur Fatihah Abdullah Bandar, Rusli Ahmad

To Link this Article: http://dx.doi.org/10.6007/IJARBSS/v10-i12/8385

DOI:10.6007/IJARBSS/v10-i12/8385

Received: 23 October 2020, Revised: 16 November 2020, Accepted: 28 November 2020

Published Online: 10 December 2020

In-Text Citation: (Teng et al., 2020)

To Cite this Article: Teng, M., Hassan, Z., Kasa, M., Nor, N. N. M., Bandar, N. F. A., \& Ahmad, R. (2020). Mediating role of Boredom in the Workplace on Turnover Intention: A Proposed Framework. International Journal of Academic Research in Business and Social Sciences, 10(12), 924-938.

Copyright: (c) 2020 The Author(s)

Published by Human Resource Management Academic Research Society (www.hrmars.com)

This article is published under the Creative Commons Attribution (CC BY 4.0) license. Anyone may reproduce, distribute, translate and create derivative works of this article (for both commercial and non-commercial purposes), subject to full attribution to the original publication and authors. The full terms of this license may be seen at: http://creativecommons.org/licences/by/4.0/legalcode

Vol. 10, No. 12, 2020, Pg. 924 - 938

Full Terms \& Conditions of access and use can be found at http://hrmars.com/index.php/pages/detail/publication-ethics 


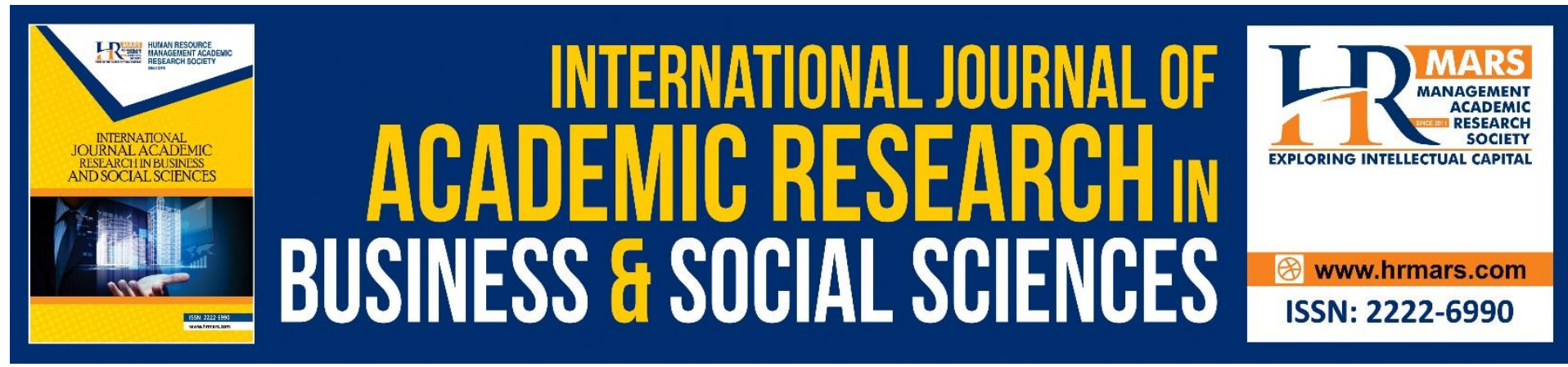

\title{
Mediating role of Boredom in the Workplace on Turnover Intention: A Proposed Framework
}

\author{
Micheal Teng ${ }^{1}$, Zaiton Hassan², Mark Kasa ${ }^{3}$, Nik Norsyamimi \\ Md Nor ${ }^{4}$, Nur Fatihah Abdullah Bandar ${ }^{5}$, Rusli Ahmad ${ }^{6}$ \\ 1, 2,4,5,6 Faculty of Cognitive Sciences and Human Development Universiti Malaysia Sarawak, \\ 94300 Kota Samarahan Sarawak ${ }^{3}$ UCSI University Malaysia, Sarawak Campus, 93450 \\ Kuching, Sarawak, Malaysia \\ Email: hzaiton@unimas.my
}

\begin{abstract}
Boredom in the workplace is commonly described as one of the negative and widespread phenomena where its increasing trend can be seen among employees on all occupational levels. However, the number of investigations performed on the occurrence of boredom in the eastern countries is limited. This study conceptualizes the causal and consequences of boredom in the workplace underpinned by the Job Demands-Resources (JD-R) theory. Subsequently, it postulates that boredom among employees occurs due to work-related characteristics (i.e.: job demands, job resources) and individual personality traits, as well as time orientation cultural dimension, which may lead to their turnover intention. Furthermore, several hypotheses are proposed in this study. This paper provides several empirical contributions by highlighting the tendency of boredom to occur in the workplace which may leads to the turnover intention. By determining its antecedents, boredom in the workplace can be curbed and the turnover intention can be prevented in a more practical way.
\end{abstract}

Keywords: Boredom in the Workplace, Job Demand Resources Theory, The Turnover Intention, Personality

\section{Introduction}

Since, four decades ago, boredom in the workplace has been identified as an important, but neglected, issue in organizational research (Fisher, 1994; Loukidou et al., 2009; Krasniqiet al., 2019). Although sounds simplistic, boredom at workplace has been identified by International Labor Office (ILO) Geneva on Stress at Work Prevention Checkpoints that alternative tasks should be provided to employees to prevent boredom. Moreover, Department of Occupational Safety and Health, Ministry of Human Resources Malaysia has identified boredom as one of the contributing factors to drugs and alcohol abuse among employees. Thus, it is important to further investigate this phenomenon because previous research demonstrated that boredom has negative impact to individuals and organizations such as job performance, attendance, wellbeing and monetary loss.

In the United Kingdom in 2006, a survey by the Training and Development Agency for Schools on 2,000 graduates aged 21 to 45, found more than half were regularly bored at work. 
The highest bored employees are from administrative and manufacturing jobs and the least bored are healthcare workers and teachers ("Teaching 'the least boring job'," 2006). This finding is in line with Fisher's (1994) proposition that academician's profession had been associated with low occupational stress, less workload, and flexible working hours.

However, the scenario is changing drastically. Globalization and increase cost of living had added more stress to academicians (Kalimo \& Hakanen, 2000) due to its need to produce the "best brain" which meets the market demand (Knight, 2002). In a recent report, academicians claimed that they applied high job demands, such as teaching, researching, sourcing grant, publishing papers, student consulting, and administrating work (Jaschik, 2013). At the same time, students' unmanageable behaviors increased the job demands applied to academicians (Chang, 2009). Moreover, previous works of literature on academicians show that there is a global association between profession and exhaustion from work (Nobile \& McCormick, 2007; Shuster \& Finkelstein, 2006) in countries including Malaysia (Makhbul \& Khairuddin, 2013; Mustapha \& Wee, 2013, Zakaria \& Asmawi, 2015). These would most likely lead to more turnover intention and absenteeism (De Croom et al., 2004).

In Malaysia, the actual academicians' turnover in private higher education institutions (PHEI) at a critical stage. According to the Ministry of Education Malaysia (2015), PHEls recorded a sudden shortfall of 8,516 academicians in 2013. From that point onward, they have been constantly facing a shortage of academicians until today (Hashim \& Mahmood, 2011). This phenomenon might be a challenge for the ministry to achieve its aim of increasing the number of academicians' enrolment, particularly in PHEls by the year 2025, as stated in the Malaysia Education Blueprint (MEB). Thus, the proposed study would like to identify: 1) what causes boredom to occur among academicians in private higher education institutions, and 2) how is it related to turnover intention?

\section{Problem Statement}

Firstly, boredom has been found to be influenced by organization and individual factors (Fisher, 1994; Mercer-Lynnet al., 2014). No known research has combined both organizational level (job demands and resources) and individual level such as personality in one study. No known research has taken into consideration cultural dimension such as, time orientation, in investigating boredom. Therefore, in this present study, personality traits namely, neuroticism and extraversion are included to develop a framework for boredom. Time orientation (monochromic versus polychronic) is also included in the study.

Secondly, Western scholars have critically emphasized exhaustion from work as one of the factors of the turnover intention rather than boredom. High employees' turnover intention in Malaysia is closely associated with low job satisfaction and organizational commitment (Yin-Fah et al., 2010; Lew, 2011; Nor \& Johari, 2011; Hassan et al., 2015; Azalea \& Mei-Hua, 2015). Not much investigation has investigated the possibility of boredom to induce turnover intention. While study showed that academicians inflicted with boredom face a higher risk of unproductivity and unpleasantness compared to those who are exhausted from work (Reijseger et al., 2013).

Thirdly, the issue of boredom has been largely studied in western context namely Netherlands (Reijseger et al., 2013; Van Wyk et al., 2016), Finland (Harju et al., 2014), United States (Bruursema et al., 2006; Watt \& Hargis, 2010), United Kingdom (Game, 2007), Italy (Guglielmia et al., 2013), Canada (Tze et al., 2014), Australia (Whiteoak, 2014) under various settings. There are limited investigations among the Eastern countries except in Pakistan (Sohail et al., 2012; Khan et al., 2019) or Malaysian context (for exception Krasniqi et al., 2019 
in petroleum company; Hasanudin et al., 2016). Boredom, although is a universal experience, it can be expected to be culture specific and culture dependent. Thus, this study will provide some insights on boredom from Eastern context by using Malaysia as an exemplar.

Nonetheless, boredom from other perspective is possibly known as a relaxation or reflection session. Darden (1999) mentioned that being bored allows employees to get their focus back to their activity. In addition, Belton and Priyadharshini (2007) interpreted boredom as a stimulus to encourage new ideas and actions. However, the negative impacts of boredom see it as the factor of an organization's deterioration.

\section{Boredom in the Workplace}

Boredom in the workplace is described as one of the widespread, contagious plaque in the modern society, which is closely associated with blue collar and white-collar employees (Heijden et al., 2012) at an increasing trend. It can be described as the feeling which builds up within the employees towards their job and the working environment when they are exposed to monotonous or repetitive activities, particularly in automation and technology-assisted environment (Cummings et al., 2016). Loukidou et al. (2009) related boredom to employees' experience in under-challenged (unpleasant) and under-stimulated (low activation) activities, while Pekrun et al. (2010) associated it with the absence of value in getting jobs done. On the other hand, Reijseger et al. (2013) defined boredom as the employee's incapability to concentrate on their jobs. Combining these descriptions altogether, boredom is defined as the state of "disconnection" of an individual in terms of cognition, emotion, and physical strength. This individual also lacks interest, passion, and attention to their job due to a nonstimulating working environment where organizational outcomes can easily be affected.

How does boredom occur? In answering this question, it is important to recognize employee's capability in relation to their job characteristics and working environment in order to achieve optimal performance. Some authors suggested that boredom occurs when the competence of employees exceeds the demands and challenges of the organization. It could be simply said that they are over-qualified for the organization. Besides, with their knowledge and the assistance received from technology, their routine job will become easier. Although these may lead to a significant increase in employees' productivity, they will start to get bored with the challenges in their line of work does not measure up to their capabilities. In other words, highly educated employees who are enrolled in lower positions in their jobs are prone to experience boredom (Leonhardt, 2009).

However, boredom is frequently neglected and is classified as an inconspicuous, "silent" emotion, as compared to other affective conditions which do not manifest disruptiveness. There is also a lower possibility of gaining mental disorder compared to the possibility of anger and anxiety. Although sounds simplistic, boredom at workplace has been identified by Department of Occupational Safety and Health, Ministry of Human Resources Malaysia as one of the contributing factors to drugs and alcohol abuse among employees. In addition, International Labor Office (ILO) Geneva on Stress at Work Prevention Checkpoints also highlighted that alternative tasks should be provided to employees to prevent boredom. It is important because previous research demonstrated that boredom has negative impact to individuals and organizations such as job performance, attendance, wellbeing and monetary loss. 


\section{Role Conflict and Boredom}

Role conflict is an important dimension of job demands. It occurs when an individual is confronting with two or more job requirements or when an individual must behave against own personal values (Brewer \& Clippard, 2002), when individual juggle with many roles (Eby et al., 2005) and there is a mismatching between job requirement and expectations. Clashes happen when demands from superior, subordinates and co-workers are conflicting. In consequence, the role overlapping nurture incompatible demands on individual which induce negative emotion resulting failure to perform the job (Cooperet al., 2001).

Taking education as an example, higher education is experiencing paradigm shift from traditional to global education, open market economy, long life education, and learner centred education (Venkatasubramanian, 2002) where it promotes "One World" and "Global Village", knowledge without barriers. Therefore, employees i.e., academicians are expected to be more responsive. One of the responds that could be capture are role conflict. They are expected to be administrator, researcher, consultant, invigilator, coordinator and lecturer. Academicians are experiencing role conflict where different responsibilities are structurally required to perform (Gmelch \& Torelli, 1994). It increases the possibility of role overloaded (Tarrant \& Sabo, 2010). On top of that, profit orientation by private universities in which put forward number of recruits further enrich academician's role. There are expected to support the growing number of students parallel with greater role (Ceylan \& Uluturk, 2006). Ability to do many roles may hinder employees from experiencing boredom. However, role conflict may also lead to boredom as employee does not know how to prioritize and where to start.

\section{Workload and Boredom}

Workload is the amount of work that need to be done within a specific duration of time. There are two perceptions of workload against boredom namely higher workload and underload. Firstly, boredom is negatively related with higher workload (Daniels, 2000). Higher workload mean employees are entrusted by organization to do more within a specific time frame. In such activating environment, they may find their job to be reversed "passive jobs" and hence, avoiding boredom. Secondly, Van Wyk et al., (2016) argued boredom is positively related to work underload. Work underload can be defined as having little things to do within a time frame (Larson, 2004) and such work does not match to the employees' competence, skills and knowledge. As a result, employees may find the job unchallenging and thus, experience boredom. Such findings are consistent with control value theory where it parks boredom as an achievement emotion arises from unpleasant and deactivating activity in due to the loss of control and value of the work (Pekrun, 2006). Therefore, as employees received greater workload, they are stimulated instead of getting bored.

\section{Job Autonomy and Boredom}

Job autonomy is "the degree to which the job provides substantial freedom, independence and discretion to the individual in scheduling the work and in determining the procedures to be used in carrying it out" (Hackman \& Lawler, 1971) and providing employees with opportunities to learn, grow and lead (Manz \& Sims, 2001). In such circumstances, em ployees may experience challenging jobs, thus impede boredom. However, (Bashir, 2011) disclosed that some may dislike job autonomy as it requires more commitment, trust and responsibility to be deployed into the job with little support (Langfred, 2004). In such circumstances, employees may experience unchallenging jobs, thus boredom is experienced. 


\section{Social Support and Boredom}

Social support is regarded as the availability of helping relationship between colleagues. Such relationship exists in term of encouragement towards job participation, guidance and attention (Rodriguez \& Cohen, 1998). In this present study, social support refers to the availability of co-workers or superiors who are friendly and communicative in solving problems encountered by employees. As noted by Nor \& Johari, the meaningful job feedback can be deemed as one of the social support element that can provided the quality of work life towards the worker. Employees are loaded researching, lecturing, marking, and recruiting as well as being administrator, invigilator, and mentor. Hence, it is believed that employees may experience lacking support in completing the tasks, which may lead to boredom.

\section{Neuroticism and Boredom}

Neuroticism is a negative personality trait with high stress sensitivity (Suls, 2001). Employees with high neuroticism are those who are associated with negative affect, inability to cope with stress, pressure and emotionally unstable. Spector et al., (2006) reported that individual with high neuroticism perceived challenging work as threatening and tends to view the world negatively. Such characteristic has predetermined that neuroticism are correlated with negative performance outcomes such as in psychological distress, job satisfaction (Judge, Heller, \& Mount, 2002) and health impairment (Bakker et al., 2010). In this present study, neuroticism is referred to the tendency of an academician experiencing distress with negative affect personality. Due to low tolerance towards challenging job with negative affect, academician with neuroticism is most likely to encounter boredom at workplace.

\section{Extroversion and Boredom}

Employees with high extroversion are those who are associated with positive affect, sociability, optimism and personal energy, that demonstrate high enthusiasm and most of the time, being active resulting greater tendency to experience positive emotions. In addition, extroverts perceived challenging work positively and rewarding in due to more favourable working conditions (Bakker et al., 2010) coupled with energized and fun-loving characteristic (McCrae \& Costa, 2003). Empirically, extroversion is linked to the positive performance outcomes such as job satisfaction (Judge, Heller, \& Mount, 2002), organizational commitment (Bakker et al., 2010) and work engagement (Langelaan et al., 2006). Thus, extrovert is less likely to experience burnout and boredom (Bakker et al., 2005).

\section{Boredom and Turnover Intention}

Boredom is regarded as a negative state of cognition, emotion and physical strength that strike employees to be deactivated and unpleasant with of their unchallenging job. Boredom as a negative wellbeing (Whiteoak, 2014) are driving employees to perform negatively such as ill health (Harju, Hakanen, \& Schaufeli, 2014), job dissatisfaction (Spector \& Fox, 2006), poor job performance (Watt \& Hargis, 2010), high absenteeism (Wan et al,, 2014), and poor organizational commitment (Van Wyk et al., 2016). Across time, turnover intention may therefore occur as employees are constantly dissatisfied with the job and organization. The final action of turnover may happen if the situation is becoming worsen and none control, and intervention exertion took place by the managers. As boredom is a negative emotion, it is most likely to expect that employee will experience turnover intention. 


\section{Workload, Boredom and Turnover Intention}

The direct relationship of workload and job burnout had been long established in the literature among scholars. In this present study, boredom at workplace will be introduced as a mediator between workload and job burnout. Based on control value theory, it is argued that as employee's loss their ability to control and value their current activity, they will experience changes in term of emotion instead of affecting wellbeing directly. On the other hand, when employees regard heavy workload as challenge, they may have lesser tendency to experience boredom and be less likely to encounter job burnout. On another hand, when employees perceived underload as unchallenging, they are prone to experience boredom and most likely to encounter job burnout.

\section{Job Autonomy, Boredom and Turnover Intention}

Job autonomy has frequently associated as determinant for intrinsic motivation that significantly related to work engagement (Demerouti et al., 2001). As employees are empowered, it engenders greater responsibility and trust in executing work which allow employees to learn, grow and lead (Manz \& Sims, 2001) through challenging task. However, some employees prefer to be followers (Bashir, 2011) instead of being authorized as it requires more commitment, trust and responsibility to be deployed into the job with little support (Langfred, 2004). In this present study, boredom at workplace will be introduced as a mediator that mediates the positive direct relationship between job autonomy and turnover intention. Guglielmi et al., (2013), provide two perspectives of job autonomy among employees.

On the positive side, job autonomy increases learning opportunities and promote employees' enthusiasm and motivation to invest effort in getting their work done. Due to that, employees are hindering boredom at workplace and receive job satisfaction which may turn down turnover intention. On the negative side, employees may view job autonomy as "extra work" which increase their responsibilities and commitment which eventually reduce their learning opportunities making the job unchallenging and bored. In addition to that, Nor and Johari (2011) emphasized that the non-meaningful job autonomy chances does contributed to the tendency to leave. Different setting of job autonomy will give different impression and adaptation to the individual. Therefore, employees receive greater job dissatisfaction. In such situation it may initiate turnover intention.

\section{Social Support, Boredom and Turnover Intention}

Social support is an important element of job resources and found to be crucial determinant for employees' turnover intention. Whenever employees are having strong social support, they are eager to work and may find their work interesting instead of getting bored and hence lowered turnover intention (Schaufeli \& Bakker, 2004; Alzyoud et al., 2015). In this present study, boredom at workplace will act as a mediator between social support and turnover intention. As the employees are overloaded, it is possible that they may have poor social support. Under such circumstance, employees who need support are most likely to be demotivated and may get bored easily as they are working alone without support. Across time, it may initiate turnover intention. On other hand, greater social support generates challenging tasks in which motivate employees to progress and invest effort by seeking assistance from co-workers or superiors. Across time, they are motivated and engaged to the work and lower turnover intention. 


\section{Neuroticism, Boredom and Turnover Intention}

Past studies had documented employees with neuroticism are closely related to negative outcomes such as psychological distress, job dissatisfaction (Judge et al., 2002) and health impairment (Bakker et al., 2010). Such findings deduced that neuroticism personality is more susceptible to boredom at workplace. According to Pekrun (2006), emotion is a response shown by employees after appraising an event and situation in term of control and value. Employee with neuroticism personality prefers to interpret events negatively and have lower tolerance towards challenging event (Spector et al., 2006). Hence, employees with such personality are most likely experiencing boredom at workplace as compare to others. High boredom may influence high turnover intention.

\section{Extroversion, Boredom and Turnover Intention}

Past studies had documented employees with extroversion are closely related to positive outcome such as job satisfaction (Judge et al., 2002) and organizational commitment (Bakker et al., 2010). In fact, Langelaan et al., (2006) reported extroversion is positively related to work engagement, specifically in the aspect of vigour (Brief \& Weiss, 2002). Such findings deduced that extroversion personality is less susceptible to boredom at workplace. According to Pekrun (2006), emotion is a response shown by employees after appraising an event and situation in term of control and value. Employee with extroversion personality is positive, energized, active and fun-loving (McCrae \& Costa, 2003). It nurtures optimal positive wellbeing (Keyes et al., 2002) in dealing with challenging task. Due to such personality, boredom is most unlikely to occur. This is supported by O'Hanlon (1981) where extroverts have a lower level of boredom at workplace as compared to introvert. Less boredom may lead to lower turnover intention.

\section{Time Orientation}

Time orientation can be divided into two, which are Monochronic and Polychronic. M-time views time as linear, an entity to be saved, spent or lost (Manrai \& Manrai, 1995). So individuals with monochronic time orientation (monochrons) prefer to complete one task at a time and adhere to a rigid appointment schedule. While promptness is important, the social context of interactions is given low importance (Manrai \& Manrai, 1995). M-time is more common in Western developed countries such as the United States and Western Europe.

In contrast, P-time views time as fluid and flexible, and polychrons prefer to work on multiple tasks before completing one (Bluedorn et al., 1992). Punctuality is negotiable and constant interruptions are tolerated (Storz, 1999). A high level of interaction among employees could be observed in polychronic) because they are more relationship oriented. P-time is more common in developing countries such as Asia (except Japan), Latin America and the Middle East (Manrai \& Manrai, 1995).

As Malaysia is still categorized as a developing country with collectivist values, it is considered as having a predominantly polychronic time orientation. According to Storz (1999), Malaysian businesspeople view time as subjective. The Malaysian 'rubber time' concept suggests that time is changeable and stretchable, therefore punctuality, deadlines, forecasting and planning are moveable. The attitude of 'rubber time' may create less boredom because the social and relational aspect of the business is more important than the business per se. 


\section{Consequences of Boredom}

Evidently, boredom in the workplace has more negative impacts on health (Harju et al., 2014), job performance (Watt \& Hargis, 2010), job satisfaction (Spector \& Fox, 2006), employees' emotion (Culp, 2006), attendance (Wan et al., 2014), and well-being (Loukidou et al., 2009), across various countries. Moreover, it leads to monetary loss at the organization level. To prove this point, Malachowski (2005) found that one-third of 10,000 United States employees spend two hours of their working hours for personal matters, and this causes a $\$ 750$ billion total loss per annum. In addition, Eddy et al., (2010) conducted a study on various occupations, and they reported that employees inflicted with boredom spend almost five hours for personal activities, such as using the Internet, emailing, making phone calls, or conversing with co-workers during the workweek.

\section{Proposed boredom framework}

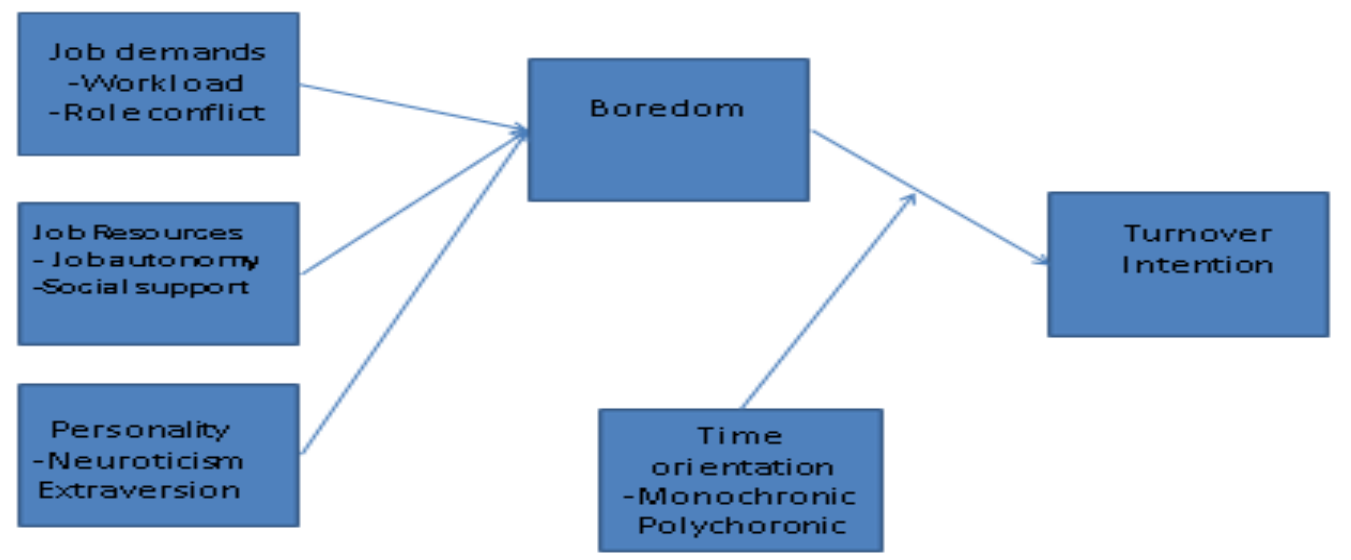

Figure 1: Conceptual Framework

\section{Summary}

The important yet unexplored issue of boredom in the workplace provides ample opportunities for research on this issue to be carried out. Boredom is possibly one of the important key elements in determining employees' turnover intention, As shown in Figure 1, the boredom framework is developed by investigating its causes, consequences and mediating as well as moderating effect. Boredom, although is a universal experience, it can be expected to be culture specific and culture dependent. Thus, this study proposes to examine cultural factor, i.e., time orientation (monochronic and polychronic) as moderator between antecedents and boredom, and boredom to consequences. Hence, identifying the root problems of boredom in the workplace, human resource practitioners will be assisted in reducing the occurrence of boredom in the workplace in more practical ways, such as job redesigning and training. Ultimately, the turnover intention will be reduced.

\section{Acknowledgement}

The study was funded by Special Grant Scheme Universiti Malaysia Sarawak 


\section{References}

Alzyoud, A. A., Othman, S. Z., \& Mohd Isa, M. F. (2015). Examining the role of job resources on work engagement in the academic setting. Asian Social Science, 11(3), 103-110. https://doi.org/10.5539/ass.v11n3p103

Azalea, A., \& Lin, M. H. (2015). Job satisfaction and turnover intention of Malaysian lecturers: Public vs. private. Paper presented at the $7^{\text {th }}$ International Conference on Humanities and Social Science, BP Samila Beach Hotel and Resort, Songkhla, Thailand.

Bakker, A., Boyd, C., Dollard, M., Gillespie, N., Winefield, A., \& Stough, C. (2010). The role of personality in the job demands-resources model: A study of Australian academic staff. Career Development International, 15(7), 622-636. https://doi.org/10.1108/13620431011094050

Bakker, A., Demerouti, E., \& Euwema, M. (2005). Job resources buffer the impact of job demands on burnout. Journal of Occupational Health Pyschology, 10(2), 170-180. https://doi.apa.org/doi/10.1037/1076-8998.10.2.170

Bakker, A., Demerouti, E., \& Verbeke, W. (2004). Using the job demands-resources model to predict burnout and performance. Human Resource Management, 43, 83-104.

Bashir, S. (2011). Organizational Cynicism Development and Testing of an Integrated Model A Study of Public Sector Employees in Pakistan [Doctoral dissertation, Mohammad Ali Jinnah University]. Islamabad. http://prr.hec.gov.pk/jspui/bitstream/123456789/1958/1/967S.pdf

Belton, T., \& Priyadharshini, E. (2007). Boredom and schooling: A cross disciplinary exploration. Cambridge Journal of Education, 37(4), 579-595. https://doi.org/10.1080/03057640701706227

Bluedorn, A. C., Kaufman, C. F., \& Lane, P. M. (1992). How many things do you like to do at once? An introduction to monochronic and polychronic time. Academy of Management Perspectives, 6(4), 17-26. https://www.jstor.org/stable/4165091

Brewer, E., \& Clippard, L. F. (2002). Burnout and job satisfaction among student support services personnel. Human Resource Development Quarterly, 13(2), 169-186. https://doi.org/10.1002/hrdq.1022

Brief, A., \& Weiss, H. (2002). Organizational behavior: Affect in the workplace. Annual Review of Psychology, 53, 297-307. https://doi.org/10.1146/annurev.psych.53.100901.135156

Ceylan, A., \& Uluturk, Y. H. (2006). The relationship between role ambiguity, role conflict, job satisfaction and performance. Dogus University Journal, 7(1), 48-58.

Chang, M. L. (2009). An appraisal perspective of teacher burnout: Examining the emotional work of teachers. Education Psychology Review, 21, 193-218. https://doi.org/10.1007/s10648-009-9106-y

Cooper, C., Dewe, P., \& O'Driscoll, M. (2001). Foundations for organizational science. Organizational stress: A review and critique of theory, research, and applications. Sage Publications, Inc.

Culp, N. (2006). The relations of two facets of boredom proneness with the major dimensions of personality. Personality and Individual Differences, 41(6), 999-1007. https://doi.org/10.1016/j.paid.2006.02.018

Cummings, M. L., Gao, F., \& Thornburg, K. M. (2016). Boredom in the worplace: A new look at at an old problem. Human Factors, 58(2), 279-300. https://doi.org/10.1177/0018720815609503 
Daniels, K. (2000). Measures of five aspects of affective well-being at work. Human Relations, 53(2), 275-294. https://doi.org/10.1177\%2Fa010564

Darden, D. (1999). Boredom: a socially disvalued emotion. Sociological Spectrum, 19(1), 1337. https://doi.org/10.1080/027321799280280

De Croom, E. M., Sluiter, J., Blonk, R. B., Broersen, J., \& Frings-Dresen, M. (2004). Stressful work, psychological job strain, and turnover: A two-year prospective cohort study of truck driver. Journal of Applied Psychology, 89(3), 442-454. https://doi.org/10.1037/0021-9010.89.3.442

Demerouti, E., Bakker, A., Janssen, P., \& Schaufeli, W. (2001). Burnout and engagement at work as a function of demands and control. Scandinavian Journal of Work, Environment \& Health, 27(4), 279-286. https://doi.org/10.5271/sjweh.615

Eby, L., Casper, W., Lockwood, A., Bordeaux, C., \& Brindley, A. (2005). Work and family research in IO/OB: Content analysis and review of the literature (1980-2002). Journal of Vocational Behavior, 66(1), 124-197. https://doi.org/10.1016/j.jvb.2003.11.003

Eddy, E. R., D'Abate, C. P., \& Thurston, J. P. W. (2010). Explaining engagement in personal activities on company time. Personnel Review, 39(5), 639-654. https://doi.org/10.1108/00483481011064181

Game, A. M. (2007). Workplace boredom coping: Health, safety, and HR implications. Personnel Review, 36(5), 701-721. https://doi.org/10.1108/00483480710774007

Fisher, S. (1994). Stress in academic life: The mental assembly line. Society for Research into Higher Education; Open University Press.

Gmelch, W. H., \& Torelli, J. A. (1994). The association of role conflict and ambiguity with administrator stress and burnout. Journal of School Leadership, 4(3), 341-356. https://doi.org/10.1177/105268469400400306

Guglielmi, D., Simbula, S., Mazzetti, G., Tabanelli, M. C, \& Bonfiglioli, R. (2013). When the job is boring: The role of boredom in organizational contexts. Work, 45(3), 311-322. https://doi.org/10.3233/wor-121528

Khan, S., Sadia, R., Hayat, S. Z., \& Tahir, S. (2019). Relationship between Academic Boredom, Learning Climate and Academic Motivation Among University Students. Pakistan Journal of Psychological Research, 621-638.

Hackman, J, R, \& Lawler, E. E. (1971). Employee reactions to job characteristics. Journal of Applied Psychology, 55(3), 259-286. https://doi.org/10.1037/h0031152

Harju, L., Hakanen, J., \& Schaufeli, W. (2014). Job boredom and its correlates in 87 Finnish organizations. Journal of Occupational and Environmental Medicine, 56(9), 911-918. https://doi.org/10.1097/jom.0000000000000248

Hashim, R., \& Mahmood, R. (2011). What is the state of job satisfaction among academic staff at Malaysian universities? Universiti Tun Abdul Razak e-Journal, 7(1), 15-26. Retrived from http://repo.uum.edu.my/id/eprint/9565

Hasanudin, S. F., Rahim, H. A. A., \& Abdullah, N. A. N. (2016). Individual differences in boredom-coping: A survey in stride, Ministry of Defence, Malaysia [Seminar paper]. Prophetic Tolerance in Diversity of Nation Seminar, Malaysia. https://www.researchgate.net/profile/Nik-Azlina-Nik-

Abdullah/publication/311648286_INDIVIDUAL_DIFFERENCES_IN_BOREDOMCOPING_A_SURVEY_IN_STRIDE_MINISTRY_OF_DEFENCE_MALAYSIA/links/58520bce 08ae95fd8e1aff41/INDIVIDUAL-DIFFERENCES-IN-BOREDOM-COPING-A-SURVEY-INSTRIDE-MINISTRY-OF-DEFENCE-MALAYSIA.pdf 
Hassan, N., Mohammad, A., Mohd, F., Rozilah, A., \& Ali, S. (2015). Religiosity perceptions on employee turnover intention in Malaysia. International Journal of Social Science and Humanity, 5(1), 120-125. https://doi.org/10.7763/IJSSH.2015.V5.436

Heijden, G. A., Schepers, J. J., \& Nijssen, E. J. (2012). Understanding workplace boredom among white collar employees: Temporary reactions and individual differences. Europen Journal of Work and Organizational Psychology, 21 (3), 349-375. https://doi.org/10.1080/1359432X.2011.578824

Jaschik, S. (2013). Who says academics aren't stressed out? Retrieved from 'http://www.theaustralian.com.au/higher-education/who-says-academics-arentstressed-out/story-e6frgcjx-1226550613135

Judge, T., Heller, D., \& Mount, M. (2002). Five-factor model of personality and job satisfaction: a meta-analysis. Journal of Applied Psychology, 87(3), 530-541. https://doi.org/10.1037/0021-9010.87.3.530

Krasniqi, V., Yulita, Idris M. A., \& Dollard, M. F. (2019). Psychosocial safety climate and job demands-resources: A multilevel study predicting boredom. In M. Dollard, C. Dormann, \& M, Awang Idris (Eds.), Psychosocial safety climate (pp. 129-148). Springer International Publishing.

Kalimo, R., \& Hakanen, J. (2000). Tyo" uupumus [Work and Health in Finland: Burnout]. In S. Virtanen (Ed.), Tyo“ja terveys Suomessa v. 2000 (pp. 119 - 126). Tyo"terveyslaitos

Keyes, C., Shmotkin, D., \& Ryff, C. (2002). Optimizing well-being: the empirical encounter of two traditions. Journal of Personality and Social Psychology, 82(6), 1007-1022. https://doi.org/10.1037/0022-3514.82.6.1007

Khan, S., Sadia, R., Zahid Hayat, S., \& Tahir, S. (2019). Relationship between academic boredom, learning climate and academic motivation among university students. Pakistan Journal of Psychology Research, 34(3), 621-638. https://doi.org/10.33824/pjpr.2019.34.3.34

Langfred, C. W. (2004). Too much of a good thing? Negative effects of high trust and individual autonomy in self-managing teams. Academy of Management Journal, 47(3), 385-399.

Langelaan, S., Bakker, A., Doornen, L. P., \& Schaufeli, W. (2006). Burnout and work engagement: Do individual differences make a difference?. Personality and Individual Differences, 40(3), 521-532. https://doi.org/10.1016/j.paid.2005.07.009

Larson, L. (2004). Internal auditors and job stress. Managerial Auditing Journal, 19(9), 11191130. https://doi.org/10.1108/02686900410562768

Leonhardt, D. (2009, March 3). Job losses show breaddth of recession. The New York Times. https://www.nytimes.com/2009/03/04/business/04leonhardt.html

Lew, T. Y. (2011). The relationships between perceived organizational support, felt obligation, affective organizational commitment and turnover intention of academics working with private higher educational institutions in Malaysia. European Journal of Social Sciences, 9(1), 72-87.

Loukidou, L., Loan-Clarke, J., \& Daniels, K. (2009). Boredom in the workplace: More than monotonous tasks. International Journal of Management Reviews, 11(4), 381-405. https://doi.org/10.1111/j.1468-2370.2009.00267.x

Makhbul, Z. M., \& Khairuddin, S. M. (2013). Stress among Malaysian academics: A conceptual study. International Journal of Academic Research in Business and Social Sciences, 2(1), 196-211. 
Malachowski, D. (2005). Wasted time at work costing companies billions. Inc. https://www.inc.com/news/articles/200507/workers.html

Manrai, L. A., \& Manrai, A. K. (1995). Effects of cultural-context, gender, and acculturation on perceptions of work versus social/leisure time usage. Journal of Business Research, 32(2), 115-128. https://doi.org/10.1016/0148-2963(94)00034-C Manz, C., \& Sims, H. (2001). The new superleadership: leading others to lead themselves. Berrett-Koehler Publishers.

Martin, I. (2009). Asia in the 2009 Times Higher Education - QS World University Rankings. Retrieved March 26, 2014, from http://www.topuniversities.com/articles/rankings/asia-2009-times-highereducation-\%E2\%80\%93-qs-world-university-rankings

McCrae, R. R., \& Costa, P. T., Jr. (2003). Personality in adulthood: A five-factor theory perspective (2nd ed.). Guilford Press. https://psycnet.apa.org/doi/10.4324/9780203428412

Mercer-Lynn, K. B., Bar, R. J., \& Eastwood, J. D. (2014). Causes of boredom: The person, the situation, or both?. Personality and Indivdual Differences, 56, 122-126. https://doi.org/10.1016/j.paid.2013.08.034

Ministry of Education Malaysia. (2015). Executive Summary Malaysia Education Blueprint 2015-2025. Putrajaya, Malaysia: Kementerian Pendidikan Malaysia.

Ministry of Human Resources Malaysia, (2004). Guidelines on Preventing and Responding To Drug And Alcohol Problems In The Workplace Occupational Safety And Health Institutional Capacity Building United Nations Development Programme (UNDP) Project Mal/99/006/A/01/Ne. Putrajaya, Malaysia: Kementerian Sumber Manusia.

Mustapha, N., \& Wee, Y. G. (2013). Examining faculty workload as antecedents of job satisfaction among academic staff of higher public education in Kelantan, Malaysia. Business and Management Horizons, 1(1), 10-16. https://doi.org/10.5296/bmh.v1i1.3205

Nobile, J. D., \& McCormick, J. (2007). Occupational stress of catholic primary staff: Investigating biographical differences. In Proceedings of the Annual Conference of the Australian Association for Research in Education (pp. 25-29). Retrived from https://doi.org/10.1108/09513541011067674

Nor, N. N., \& Johari, H. (2011). Turnover Intention: An Examination of Job Characteristics And Transactional Leadership Style Among Operators In Electrical And Electronics SubSector [Master's Thesis, Universiti Utara Malaysia]. Malaysian Thesis Online. http://myto.upm.edu.my/find/Record/my-uum-etd.3415

O'Hanlon, J. (1981). Boredom: practical consequences and a theory. Acta Psychologica, 49(1), 53-82. https://doi.org/10.1016/0001-6918(81)90033-0

Pekrun, R. (2006). The control-value theory of achievement emotions: Assumptions, corollaries and implications for educational research and practice. Educational Psychology Review, 18, 315-341. https://doi.org/10.1007/s10648-006-9029-9

Pekrun, R., Goetz, T., Daniels, L., Stupnisky, R., \& Perry, R. (2010). Boredom in achievement settings: Exploring control-value antecedents and performance outcomes of a neglected emotion. Journal of Educational Psychology, 102(3), 531-549. https://doi.org/10.1037/a0019243

Reijseger, G., Schaufeli, W., Peeters, M. C. W., Taris, T., Van, B. I., \& Ouweneel, E. (2013). Watching the paint dry at work: psychometric examination of the Dutch Boredom Scale. Anxiety Stress Coping, 26(5), 508-525. 
https://doi.org/10.1080/10615806.2012.720676

Rodriguez, M., \& Cohen, S. (1998). Social support: Encyclopedia of Mental Health. Academic Press.

Schaufeli, W., \& Bakker, A. (2004). Job demands, job resources and their relationship with burnout and engagement: a multi-sample study. Journal of Organizational Behavior, 25(3), 293-315. https://doi.org/10.1002/job.248

Sohail, N., Ahmad, B., Tanveer, Y., \& Tariq, H. (2012). Workplace boredom among university faculty members in Pakistan. Interdisciplinary Journal of Contemporary Research in Business, 3(10). Retrived from https://journalarchieves15.webs.com/919-925.pdf

Shuster, J. H., \& Finkelstein, M. J. (2006). The American faculty: The restructuring of academic work and careers. Baltimore, MD: John Hopkins University Press.

Spector, P. E., Fox, S., Penney, L. M., Bruursema, K., Goh, A., \& Kessler, S. (2006). The dimensionality of counterproductivity: Are all counterproductive behaviours created equal? Journal of Vocational Behaviour, 68(3), 446-460.

https://doi.org/10.1016/j.jvb.2005.10.005

Suls, J. (2001). Affect, stress, and personality. In J. P. Forgas (Ed.), Handbook of affect and social cognition (pp. 392-409). Lawrence Erlbaum Associates.

Storz, M. L. (1999). Malay and Chinese values underlying the Malaysian business culture. International Journal of Intercultural Relations, 23(1), 117-131. https://doi.org/10.1016/S0147-1767(98)00028-5

Tarrant, T., \& Sabo, C. E. (2010). Role conflict, role ambiguity, and job satisfaction in nurse executives. Nursing Administration Quarterly, 34(1), 72-82.

10.1097/NAQ.0b013e3181c95eb5

Venkatasubramanian, K. (2002). Financing of higher education. The Hindu.

Van Wyk, S., De Beer, L., Pienaar, J., \& Schaufeli, W. B. (2016). The psychometric properties of a workplace boredom scale (DUBS) within the South African context. SA Journal of Industrial Psychology, 42(1) . https://doi.org/10.4102/sajip.v42i1.1326

Wan, H., Downey, L., \& Stough, C. (2014). Understanding non-work presenteeism: Relationships between emotional intelligence, boredom, procrastination and job stress. Personality and Individual Differences, 65, 86-90. https://doi.org/10.1016/j.paid.2014.01.018

Watt, J., \& Hargis, M. (2010). Boredom proness: its relationship with subjective underemployment, perceived organizational support and job performance. Journal of Business and Psychology, 25(1), 163-174. https://doi.org/10.1007/s10869-009-91389

Whiteoak, J. W. (2014). Predicting boredom-coping at work. Personnel Review, 43(5), 741763. https://doi.org/10.1108/PR-09-2012-0161

Yin-Fah, B. C., Foon, Y. S., Chee-Leong, L., \& Osman, S. (2010). An Exploratory Study on Turnover Intention among Private Sector Employees. International Journal of Business and Management5(8), , 57-64. https://doi.org/10.5539/ijbm.v5n8p57

Zakaria, S., \& Asmawi, A. (2015). Work Responsibilities Stress among Academicians in Private Universities in Malaysia. Journal of Education and Vocational Research, 6(2), 42-47. https://bit.ly/3oTZmnB

Teaching 'the least boring job'. (2006). BBC News.

http://news.bbc.co.uk/2/hi/uk_news/education/5217736.stm 
INTERNATIONAL JOURNAL OF ACADEMIC RESEARCH IN BUSINESS AND SOCIAL SCIENCES

Vol. 10 , No. 12, 2020, E-ISSN: $2222-6990$ @ 2020 HRMARS

Tze, V. M. C., Daniels, L. M., \& Klassen, R. M., (2016). Evaluating the relationship between boredom and academic outcomes: A meta-analysis. Educational Psychology Review, 28, 119-144. https://doi.org/10.1007/s10648-015-9301-y 